\title{
Determination of gushing potential of barley
}

\author{
Sylvie Bělákovái ${ }^{*}$, Tomáš Foltýn ${ }^{1}$, Natálie Belcredi Březinová2 ${ }^{2}$, Marek Pernica ${ }^{1}$, Rastislav Boško ${ }^{1,2}$, \\ Zdeněk Svoboda ${ }^{1}$, Karolína Benešová ${ }^{1}$ \\ 1 Research Institute of Brewing and Malting, Mostecká 7 , \\ 61400 Brno, Czech Republic \\ 2 Department of Crop Science, Breeding and Plant Medicine, \\ Mendel University in Brno Zemědělská 1, 61300 Brno, \\ Czech Republic \\ *corresponding author: belakova@ beerresearch.cz
}

\section{ABSTRACT}

A new control method for the determination of the malting barley susceptibility to gushing was developed. The method is based on the modified Carlsberg test (MCT) after prior stimulation of barley with substances that promote the germination process.

Barleys from the harvest of 2020 and malts produced from them were used to develop and verify the method. The selection of barleys was based on the results of gushing potential detected in the produced malts. To optimise and verify the method, the barley variety Sunshine with a high gushing potential of both barley $(139 \pm 33 \mathrm{~g})$ and malt $(144 \pm 13 \mathrm{~g})$, and the barley variety Pionier with zero gushing potential of both barley and malt were used.

Malt was produced from the Lodestar barley variety with a high content of the mycotoxin deoxynivalenol. Gushing of the malt was $127 \pm 10 \mathrm{~g}$. The gushing potential in barley was determined by the MCT method after prior stimulation of germination. For comparison, the gushing potential was also determined by the MCT method without stimulation of germination. It was proved that stimulation of germination is a key process for correct determination of the susceptibility of barley to gushing.

The newly developed method was used for the determination of the gushing potential of five barleys from the harvests of 2020 and 2021. Control gushing determination of five malt samples was performed using the MCT method. An agreement between the measured data was found.

Key words: barley, malt, gushing, MCT, germination stimulation

\section{Introduction}

The brewing and beverage industry still faces a problem of gushing (Christian et al., 2010). This phenomenon negatively affects an image of beer and incurs economic losses to breweries and maltsters (Sarlin et al., 2005).

The phenomenon of gushing is characterized by over-foaming immediately after a bottle opening. That means the release of excess pressure above beer causes formation of a very high number of fine bubbles in the entire volume of a beer which ascend very quickly, creating foam. This foam flows out of the bottle or, in severe cases, actually spurts from the bottle (Gjertsen, 1967).
The principle of this relatively complex phenomenon is an immediate release of carbon dioxide after the bottle opening (Shokribousjein et al., 2011).

Based on its causes, gushing can be divided into "primary" and "secondary". While the primary gushing of beer is related to malt quality, the secondary one may be attributed to malt processing in the brewery (Gjertsen et al., 1963). Secondary gushing can generally be managed using good manufacturing practices and appropriate process control and design (Specker, 2014) In contrast to secondary gushing, the primary gushing occurs periodi- 
cally and epidemically after extremely humid summers. It affects the entire production volume of beer produced from one malt lot (Casey, 1996). The most important factor in the induction of primary gushing is an infection of cereals with filamentous fungi that produce surface-active proteins, so called hydrophobins (Postulkova et al., 2016). Not only hydrophobins, but also fungispumins and elevated levels of pathogenesis-related proteins (PRs) may be related to the occurrence of gushing (Mastenjevič et al., 2018).

There are a few gushing prediction methods developed for malt, wort, beer, and other beverages. Since gushing is a very specific phenomenon, it is difficult to obtain reliable results. The substances causing gushing are rarely identified but the potential of raw materials for gushing can be determined (Mastanjevič et al., 2017).

The prediction of gushing from raw materials depends on a conversion of substances causing gushing from malt into a solution that is carbonated or added to a carbonated beverage, often soda water. Basic representatives of these procedures are the Carlsberg Test (Vaag et al., 1993), the Modified Carlsberg Test (MCT) and the Weihenstephaner Test (Christian et al., 2011).

The aim of this study was to develop a new control method for determining the prediction of gushing directly in barley. The purpose of this method is not to identify and quantify substances that induce gushing but to identify the susceptibility of malting barley to gushing without a malting process.

\section{Material and Methods}

\section{Samples}

To optimize the method of gushing prediction in barley, two samples of spring barley varieties (Sunshine and Pionier) and malts produced from them (these samples were provided by Sladovny Soufflet ČR, a.s.) and one sample of spring barley (Lodestar variety), which was malted in the micromalting plant of the Malting Institute in Brno (Research Institute of Brewing and Malting), were used.

Five samples of barley and malt (varieties Irina, Donau, Tosca, KWS Irina and Overture) were used to verify the gushing potential of barley. The samples were supplied by malt producers in the Czech Republic.

The samples originated from the harvests of 2020 and 2021.

\section{Prediction of gushing in barley}

The method is based on a patent (Kosař, 2010) and involves an extraction procedure using a medium that supports the germination process. The obtained extract was subjected to a gushing test using a modified Carlsberg method (MCT).

The barley grain sieving fractions over $2.5 \mathrm{~mm}$ were used for the determination. There was $400 \mathrm{ml}$ of a solution containing $0.75 \%$ hydrogen peroxide and gibberellic acid at a concentration of $0.127 \mathrm{nmol}$ added to $100 \mathrm{~g}$ of the barley sample. The beaker was placed in a water bath heated to $37{ }^{\circ} \mathrm{C}$ and incubated for 24 hours. The liquid portion was then removed and only the solid portion of the grain was used for further analysis.

The grain was watered with $350 \mathrm{ml}$ of deionized $\mathrm{H}_{2} \mathrm{O}$ and the entire content was mixed at maximum speed ( $252 \mathrm{RCF}$ ) for $120 \mathrm{~s}$. The aqueous extract was centrifuged and the modified Carlsberg method (MCT) was then used to determine the gushing potential of the malt.

\section{Modified Carlsberg Test (MCT)}

The gushing test of malt was performed according to the Modified Carlsberg Test (MCT) with minor modifications (MEBAK, 2018). The sample preparation was described in detail by Piacentiny et al. (2021). An aqueous extract $(50 \mathrm{ml})$ of coarse malt grist was added to carbonated water (6.5-6.9 g/ $\mathrm{CO}_{2}$ ) and the bottles were shaken for three days. After shaking, the bottles were kept still for $10 \mathrm{~min}$, inverted three times and opened after $30 \mathrm{sec}$. The amount of gushing was determined based on the change in weight of the bottle.

\section{Malting process}

A grain sample $(0.5 \mathrm{~kg})$ was malted in the micromalting plant of the KVM company (CR). The method traditionally used in the Research Institute of Brewing and Malting, which is almost identical with the MEBAK (2011) method, was used for laboratory malting.

Briefly, on the $1^{\text {st }}$ day of steeping, water was added to the grain for $5 \mathrm{~h}$, followed by $19 \mathrm{~h}$ of an air rest. On the $2^{\text {nd }}$ day, grains were submitted to $4 \mathrm{~h}$ in water, followed by $20 \mathrm{~h}$ of an air rest. Finally, on the $3^{\text {rd }}$ day of steeping, the grains were in water for $20 \mathrm{~min}$ and then submitted to an air rest for $23 \mathrm{~h}$ and $40 \mathrm{~min}$. The germination step was performed over 3 days $(72 \mathrm{~h}$ ), with a subsequent kilning step. The grain was maintained at a controlled temperature $\left(14{ }^{\circ} \mathrm{C}\right)$ during the steeping and germination processes and the moisture content of the grain was measured in each step, maintained at $45 \%$. The total kilning time was $22 \mathrm{~h}$, with a pre-kilning temperature of $55^{\circ} \mathrm{C}$ for $12 \mathrm{~h}$ and a kilning temperature of $80^{\circ} \mathrm{C}$ for $4 \mathrm{~h}$.

\section{Determination of mycotoxin deoxynivalenol by the ELISA method}

A ground barley or malt sample ( $20 \mathrm{~g}$ ) was extracted with $100 \mathrm{ml}$ of deionized $\mathrm{H}_{2} \mathrm{O}$, shaken for $50 \mathrm{~min}$, centrifuged 
at $4000 \mathrm{rpm}$ for $15 \mathrm{~min}$, an aliquot of the supernatant $(100 \mu \mathrm{l})$ was diluted according to instructions or used directly for the analysis. DON concentration was determined using a competitive ELISA test kit as instructed by the kit manufacturer (Svoboda et al., 2019).

\section{Results and Discussion}

\section{Determination of the gushing potential of barley}

To optimize the method, a sample of barley variety Sunshine (A) where the produced malt showed high gushing was selected. A sample of barley variety Pionier (B) where the produced malt had zero gushing was used as the control (Table 1). Gushing of malt was determined by the MCT method in triplicate.

\section{Evaluation of the methods with and without germination stimulation for determining the gushing potential}

The method for determining the gushing potential of barley with germination stimulation was compared to the MCT method without germination stimulation. A sample of barley variety Lodestar (C) with a high mycotoxin DON content $(4081 \pm 388 \mu \mathrm{g} / \mathrm{kg})$ was selected for a comparison of two mentioned methods. The selection was made based on the assumption that contaminated barley would also show a high gushing potential in the malt. Schwarz et al. (1996) reported that approximately $90 \%$ of all malts containing DON were prone to gushing. On the other hand, Sarlin et al. (2005) reported that hydrophobins and DON in malts showed no correlation with gushing. This implies that a DON content and the gushing poten-

Table 1 Characteristics of samples used for the method development

\begin{tabular}{|c|c|c|c|}
\hline Sample No. & Identification & Variety & $\begin{array}{c}\text { Gushing of malt } \\
\text { (MCT) }\end{array}$ \\
\hline A & Spring barley & Sunshine & $144 \pm 13 \mathrm{~g}$ \\
\hline B & Spring barley & Pionier & $<4 \mathrm{~g}$ \\
\hline
\end{tabular}
tial of malt are not related. In our case, however, the relationship between DON and gushing was demonstrated.

The sample was malted in the micro malting plant of the Malting Institute in Brno (Research Institute of Brewing and

Barley A samples were prepared in four replicates on 4 independent days (16 determinations in total). Each sample was placed in 4 bottles of sparkling water. The results of the measurements are shown in Figure 1.

The measured values of the gushing potential of barley ranged from 98 to $174 \mathrm{~g}$, with an outlying value of $37 \mathrm{~g}$ (Grubb's test). The mean value was $139 \mathrm{~g}$, median $148 \mathrm{~g}$, and relative standard deviation $24 \%$.

Barley B samples were prepared in parallel with A samples ( 4 replicates in 4 bottles). The gushing potential of barley B was $<4 \mathrm{~g}$ in all cases.
Malting) using the standard malting procedure (MEBAK, 2011). In the produced malt, the mycotoxin DON level of $3613 \pm 343 \mu \mathrm{g} / \mathrm{kg}$ was found. The MCT gushing test was conducted in the relevant malt (MEBAK, 2018). The average gushing value of the malt was $124 \pm 10 \mathrm{~g}$.

The gushing potential of barley was determined using a MCT-based method after prior stimulation of barley germination with hydrogen peroxide and gibberellic acid extraction solution. The gushing potential of barley was $182 \pm 31 \mathrm{~g}$.

For comparison, also the MCT method without stimulation of germination was employed. This method is suitable and commonly used for the determination of the gushing potential of malt. The resulting gushing potential of barley by this classical method was $107 \pm 16 \mathrm{~g}$.

The Figure 2 shows that the gushing potential of barley is significantly higher when the MCT method is used with germination stimulation. This increase is due to gushing factors that occur during germination of barley infected with moulds. This is fully consistent with the known facts that malt gushing is the result of interactions between fungus and actions that take place in barley during germination (Gjertsen, 1965). The gushing factors produced by fungus are

Figure 1 The values of gushing potential of barley 
already present in barley but can also be formed during malting (Munar and Sebree 1997, Aastrup 1995).

\section{Method application}

To verify the method, five samples of barley from the harvests of 2020 and 2021 and malts made from them were used. The gushing potential of barley was determined by the MCT method after previous stimulation of germination. Malt gushing was determined by MCT. The results are shown in Table 2.

The measurements confirmed a possibility to use the method for a prediction of gushing directly in barley. The results of the gushing potential in barley are fully consistent with the results detected in malt.

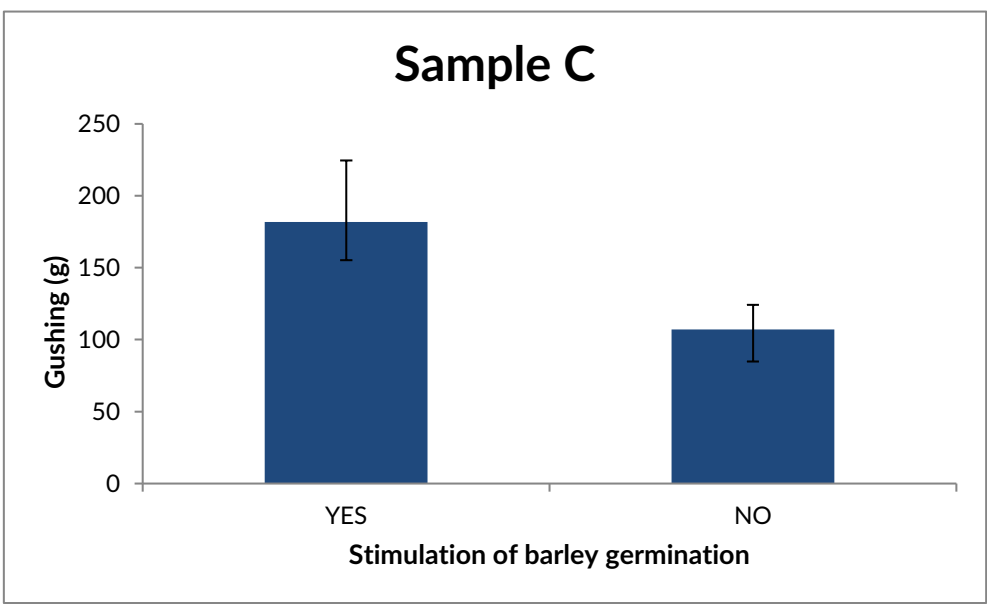

Figure 2 The average values of the gushing potential of barley by the MCT method

Table 2 Verification of the method on real barley and malt samples

\begin{tabular}{|c|c|c|c|c|}
\hline Sample No. & Variety & Harvest & $\begin{array}{c}\text { Barley } \\
\text { Gushing potential }\end{array}$ & $\begin{array}{c}\text { Malt } \\
\text { Gushing potential }\end{array}$ \\
\hline 1 & Irina & 2020 & $<4 \mathrm{~g}$ & $<4 \mathrm{~g}$ \\
\hline 2 & Donau & 2020 & $<4 \mathrm{~g}$ & $<4 \mathrm{~g}$ \\
\hline 3 & Tosca & 2021 & $53 \pm 14 \mathrm{~g}$ & $40 \pm 9 \mathrm{~g}$ \\
\hline 4 & KWS Irina & 2021 & $49 \pm 10 \mathrm{~g}$ & $<4 \mathrm{~g}$ \\
\hline 5 & Overture & 2021 & $<4 \mathrm{~g}$ & $\mathrm{~g}$ \\
\hline
\end{tabular}

\section{Conclusion}

An operational method for the determination of the gushing potential of barley was optimized. The method includes gushing factors that occur during germination of barley. Using this method, it is possible to discard barley susceptible to over-foaming before malting; this can have a major economic impact on the quality of malt and beer production.

\section{Acknowledgement}

The study was supported by the Ministry of Agriculture of the Czech Republic, within Institutional Support MZERO 1918.

\section{References}

Aastrup, S. (2003). Gushing factors are already present in barley allowing early detection of gushing risk. In Proceedings of the European Brewery Convention Congress, Dublin (pp. 923-929). Nürnberg: Fachverlag Hans Carl.

Casey, G. P. (1996). Primary versus secondary gushing and assay procedures used to assess malt/beer gushing. MBAA Technical Quarterly, 33(4), 229-235.

Chrisitian, M., Titze, J., Ilberg, V., Jacob, F. (2010). Combined particle analysis as a new tool to predict gushing shown with alcohol-free beverage products. Brewing Science, 63, 72-79.

Christian, M., Titze, J., Ilberg, V., Jacob, F. (2011). Novel perspectives in gushing analysis: A review. Journal of the Institute of Brewing, 117(3), 295-313. https://doi.org/10.1002/j.2050-0416.2011.tb00474.x

Gjertsen, P. (1967). Gushing in beer; its nature, cause and prevention. Brewer's Digest, 42, 80-84.

Gjertsen, P., Trolle, B., Andersen, K. (1963). Weathered barley as a contributory cause of gushing in beer. In Proceedings of the 9th Congress - European Brewery Convention, Brussels (pp. 320-341). Amsterdam: Elsevier.

Gjertsen, P., Trolle, B., Andersen, K. (1965). Gushing caused by microorganisms, specially Fusarium species. In Proceedings of the 10th Congres - European Brewery Convention, Stockholm (pp. 428-438). Amsterdam: Elsevier.

Kosař, K. (2010). Method for determining final re-foaming of packaged beer due to barley. Patent No. 302041. Prague: Industrial Property Office of the Czech Republic. 
Mastanjevic, K., Krstanovic, V., Mastanjevic, K., Sarkanj, B. (2018). Malting and brewing industries encounter Fusarium spp. related problems. Fermentation, 4(1), 1-15. https://doi.org/10.3390/fermentation4010003

Mastanjević, K., Mastanjević, K., Krstanović, V. (2017). The gushing experience-a quick overview. Beverages, 3(2), 25. https://doi. org/10.3390/beverages3020025

MEBAK. (2011). Raw materials: barley, adjuncts, malt, hops and hop products. In J. Fritz (Ed.), Collection of brewing analysis methods of the Mitteleuropäische Brautechnische Analysenkommission (MEBAK) (p. 341). Germany: Freising-Weihenstephan.

MEBAK. (2018). Raw materials: barley, adjuncts, malt, hops and hop products. In J. Fritz (Ed.), Collection of brewing analysis methods of the Mitteleuropäische Brautechnische Analysenkommission (MEBAK) (p. 341). Germany: Freising-Weihenstephan.

Munar, M. J., Sebree, B. (1997). Gushing-a maltster's view. Journal of the American Society of Brewing Chemists, 55(3), 119-122. https://doi. org/10.1094/ASBCJ-55-0119

Piacentini, K. C., Běláková, S., Rocha, L. O., Savi, G. D., Benešová, K., Pernica, M., ... Correa, B. (2021). Gushing phenomenon and gene Hyd5 from Fusarium species in barley samples from Brazil. Kvasny Prumysl, 67(2), 435-441. https://doi.org/10.18832/kp2021.67.435

Postulkova, M., Riveros-Galan, D., Cordova-Agiular, K., Zitkova, K., Verachtert, H., Derdelinckx, G., ... Branyik, T. (2016). Technological possibilities to prevent and suppress primary gushing of beer. Trends in Food Science \& Technology, 49, 64-73. https://doi.org/10.1016/j. tifs.2015.12.006
Sarlin, T., Nakari-Setala, T., Linder, M., Penttila, M., Haikara, A. (2005). Fungal hydrophobins as predictors of the gushing activity of malt. Journal of the Institute of Brewing, 111(2), 105-111. https://doi. org/10.1002/j.2050-0416.2005.tb00655.x

Schwarz, P. B., Beattie, S., Casper, H. H. (1996). Relationship between Fusarium infestation of barley and the gushing potential of malt. Journal of the Institute of Brewing, 102(2), 93-96. https://doi. org/10.1002/j.2050-0416.1996.tb00899.x

Shokribousjein, Z., Deckers, S., Gebruers, K., Lorgouilloux, Y., Baggerman, G., Verachtert, H., ... Derdelinckx, G. (2011). Hydrophobins, beer foaming and gushing. Cerevisia: Belgian Journal of Brewing and Biotechnology, 35(4), 81-101. Retrieved from https://lirias.kuleuven. be/retrieve/143973\$DReview_Hydrophobins_beer_foaming_and_ gushing_Cerevisia 2011.pdf

Specker, C., Niessen, L., Vogel, R. F. (2014). In vitro studies on the main beer protein $\mathrm{Z} 4$ of Hordeum vulgare concerning heat stability, protease inhibition and gushing. Journal of the Institute of Brewing, 120(2), 85-92. https://doi.org/10.1002/jib.118

Svoboda, Z., Mikulikova, R., Benesova, K., Belakova, S. (2019). The occurrence of the selected Fusarium mycotoxins in Czech malting barley, harvested in 2012-2017. Czech Journal of Food Sciences, 37(6), 439-445. https://doi.org/10.17221/317/2018-CJFS

Vaag, P., Riis, P., Knudsen, A. D., Pedersen, S., Meiling, E. (1993). A simple and rapid test for gushing tendency in brewing materials. In Proceedings of the 24th Congress - European Brewery Conventio (pp. 155-162). Oslo: IRL Press, Oxford. 